\title{
NON-AGENDA
}

With the view of causing an increase to take place in the mass of national wealth, or with a view to increase of the means either of subsistence or enjoyment, without some special reason, the general rule is, that nothing ought to be done or attempted by government. The motto, or watchword of government, on these occasions, ought to be - Be quiet...Whatever measures, therefore, cannot be justified as exceptions to that rule, may be considered as non-agenda on the part of government.

- Jeremy Bentham (c.1801)

\section{Are There Votes in Higher Taxes?}

\section{Andrew Norton}

$\mathrm{P}$ olitical conventional wisdom assumes that tax cuts attract votes. Yet since the late 1990s the opinion poll evidence supporting this belief has weakened. In 1998, for the first time since 1969, a majority did not support 'less tax', when the choice was that or more spending on social services. By 2003, asked whether they would forgo tax cuts or pay higher tax to fund health and education services majorities said 'yes'. Anomalies exist - a belief that the top marginal tax rate is too high, for example — but too many surveys from too many polling organisations say similar things to doubt the general trend. Tax is less unpopular than in the past.

Unsurprisingly, supporters of big government are keen to enlist these results in their cause. The ACTU (2003) highlighted its own poll showing that 'the community values public provision of health and education ahead of individual tax cuts'. Shaun Wilson (2004), a left-leaning academic and key public opinion researcher in this field, interprets the results as saying that 'the public wants its government to follow enlightened social democracies elsewhere and invest in their future'. John Quiggin (2004), a prominent left-of-centre economist, hopes that these polls mean 'that social democracy has won the public debate, at least for the moment'.

Politicians seem less convinced. In the May 2004 Budget, the Coalition government announced tax relief for people earning over $\$ 52,000$ a year, and no significant new spending on health and education, though in the lead-up to the October 2004 election increased health spending was announced. The ALP Opposition passed these tax cuts, and promised to reduce taxes for people earning

Andrew Norton is a Research Fellow at The Centre for Independent Studies. He is currently writing a short book on public opinion about economic reform. 
less than \$52,000 a year if it won office. Opposition Leader Mark Latham (2004) went so far as to say, in his reply to the Budget, that Labor would reduce 'Commonwealth expenditure and Commonwealth taxation as a proportion of GDP'.

The politicians seem to think that talk is cheap - that it is easy for voters to tell pollsters that they want to pay more tax, but that in reality there would be an electoral price to pay. As professionals in the business of politics they know that there are many real and potential problems with opinion polls, which is why they like to say that it is only the poll on election day that counts. Some reasons why they might be right in thinking that tax increases are not a prudent electoral strategy are explored later in this article. However, first it is argued that there has in fact been a shift in public opinion about taxing and spending, though not for the reasons suggested by other recent analysts of these trends.

\section{The Polls}

\section{Long-term trends}

Since 1967, in a series of slightly varying questions, voters have been asked about their relative preference for reducing tax or spending more on social services. These surveys are not in themselves good guides for politicians. They omit an option that is always popular if available, the status quo. They leave implicit the higher tax corollary of more spending, and the lower spending corollary of less tax, creating an artificial choice between two positives. They ask about what the government should do, not whether the respondent personally wants less tax or more social services. As we will see, these issues are potentially significant. These surveys' value lies in tracking broad tendencies in opinion over a long period of time, letting us hypothesise more confidently about their links to realworld trends than we can from one-off polls with very different questions.

As can be seen in Figure 1, the peak in pro-service spending opinion occurred in the late 1960s, and lasted for two surveys. By the time voters were asked again about their relative preferences for taxing and spending, in 1974, support for more spending had halved and twice as many respondents as before wanted less tax. In the mid-1980s the lower tax option increased its popularity, with very few people wanting more social service spending. Though the anti-tax view subsided from its 1980s peak in the first half of the 1990s, it was still a majority position, and support for more spending remained at low levels. In the second half of the 1990s, opinion began to change, with less tax trending down and more spending trending up. By 1998 'reducing taxes' was a minority position, though still a larger minority than 'spending more'. In 2003 a question similar to those of 19672001, but one which replaced the vague 'social services' with 'services like health and education' gave spending a plurality on 48 per cent, with 28 per cent for less tax. A year on, a 2004 Saulwick-Muller poll came out with near even support for less tax and fewer services (45 per cent) and more tax and more services (44 per cent), the more tax option being six percentage points higher than it had been in 
the same poll in 2001. This poll's question and response options differ from those in the time series, but it shows the some broad trends (Saulwick and Muller, 2004).

Figure 1: Long-Term Trends in Opinion on Taxing and Spending

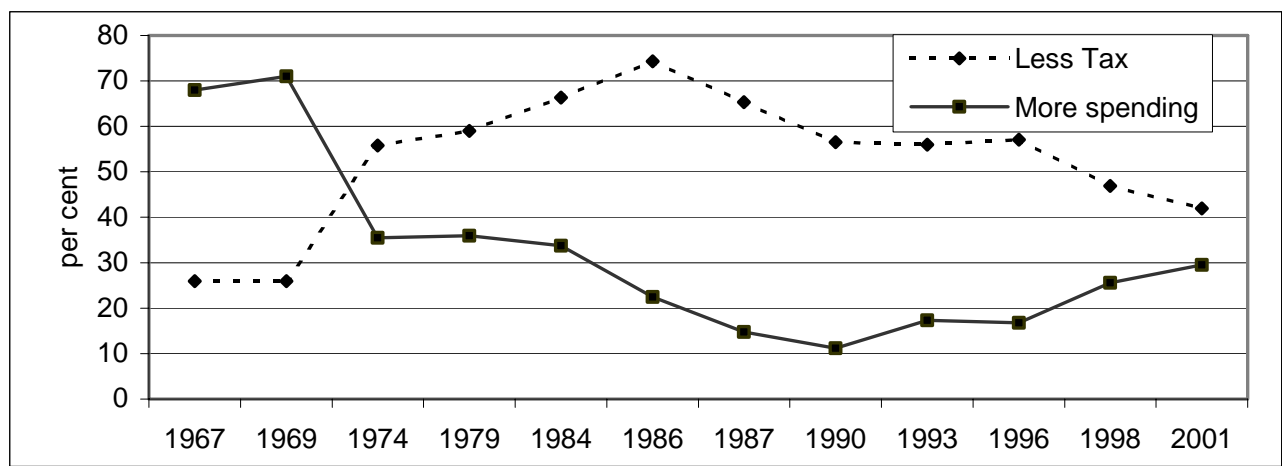

Questions:

- $\quad 1967,1969$ and 1979 ANPAS surveys; 1984-1986 National Social Science Surveys; 1987 and 1993-2001 Australian Election Survey: If the government had a choice between reducing taxes or spending more on social services, which do you think it should do?

- 1974 Morgan Poll: If you had to choose between the federal government increasing social services or reducing taxes which would you choose?

- 1990 Australian Election Survey: Some people think that the federal government should reduce taxes a lot and spend much less on social services. Others think that the federal government should increase taxes a lot and spend much more on social services. And others have opinions in between. Where would you place yourself on this scale?

Where grades of support for taxing and spending were available, in all polls from 1986-87 onwards, responses have been aggregated. Following the practice of other researchers, the 1984 and 1986 National Social Science Survey 'mildly for' more taxing and spending have been translated as being equivalent to 'depends' in subsequent surveys. The argument for doing so is that there is a consistently large minority (20-32 per cent) of equivocal respondents who choose this option, so including them in either lower tax or more spending overstates support for these options.

\section{Recent one-off surveys}

Other surveys over the last two years also show support for more spending. A 2003 ACNielsen survey taken after the May Budget changed the choice from alternative principles to alternative proposals. The Budget offered a small tax cut, equivalent to $\$ 4$ a week for middle-income earners. Of those polled, 20 per cent preferred the tax cut, and 77 per cent wanted the money from the tax cut to go to 'services such as health and education' (Stirton, 2003). Though the tax cut's trivial size may have affected the trade-off, this was a strong pro-spending result 
for a survey that reminded its respondents that government expenditure was not costless.

Later in 2003, the Australian Survey of Social Attitudes (ASSA) looked at spending priorities and personal willingness to pay, again prompting respondents to consider the potential personal financial consequences of their answers. It found 68.2 per cent were willing to pay extra tax to spend more on health and Medicare, 63.5 per cent for schools, 54.6 per cent for defence and national security, and 53.8 per cent for environmental protection. All up, 73 per cent nominated at least one area in which they were prepared to pay more tax (Wilson and Breuch, 2004:110).

Newspoll arrived at a similar result in January 2004. It asked 'If the federal government has a large surplus, should this be spent all or mainly on health and education, on personal tax cuts, or spent on both equally?' and 72 per cent of respondents said it should be spent all or mainly on health and education, nine per cent supported tax cuts, and 14 per cent wanted it spent on both equally. All up, 88 per cent favoured at least some additional spending. The numbers were a little lower in a Taverner Research poll of voters in NSW and Victoria after the May 2004 Budget. This Budget offered generous payments to families as well as tax cuts for people earning over $\$ 52,000$ a year. When its respondents were asked whether they would forgo the tax cuts and family incentives for spending on services 65 per cent said 'yes, definitely', 14 per cent wanted some of each, and 18 per cent wanted the tax cuts (Hudson, 2004). The two pro-spending options add up to 79 per cent, comparable to ACNielsen and ASSA results in 2003.

On-line polling conducted by researchers from the Australian National University on behalf of The Bulletin during the 2004 federal election campaign confirmed that opinion still favoured tax increases (Gibson, 2004). When asked if they would be willing to pay higher taxes so that the government could afford to spend more on health and Medicare 69 per cent of respondents said that they were. Majority affirmative responses were also received for education (51 per cent), environmental protection (55 per cent) and defence and national security (52 per cent).

\section{Explaining Discrepancies}

While all polls conducted on taxing and spending issues over 2003 and 2004 arrive at similar conclusions, there is an anomaly that needs explaining. The most general 2003 question about reducing tax or increasing spending on services, from the ASSA, shows 48 per cent support for the more spending option. That is at least 24 percentage points lower than levels recorded in other polls, despite the general question only implying that more services meant more tax, and not mentioning at all that the respondent's personal tax bill may be higher. How is this to be explained? 


\section{Specific spending}

Part of the answer is that voters have reasonably clear ideas about which parts of the Budget should receive more resources. When the 2003 ASSA, for example, looked at five specific outlay options, 73 per cent of respondents nominated at least one of these for additional taxing and spending, but only 27 per cent wanted more in all five areas.

Other poll evidence confirms impressions from the 2003 ASSA and the January 2004 Newspoll that health is a high priority. Over many years the Morgan Poll has asked its respondents about what are the most important issues the federal government should be doing something about (a national issue), and what the federal government could do that would be of most benefit to them and their families (a personal issue). As Figure 2 shows, health has increased very significantly as a top issue since the early 1990s. The difference between the national and personal levels is exaggerated, since for the national question respondents are specifically asked for three issues, while no number is mentioned for personal replies (respondents can give more than one answer, but in practice few do). Newspoll's surveys also show that health has become a more important issue (Grant, 2004:18).

\section{Figure 2: The Rise of Health as an Issue}

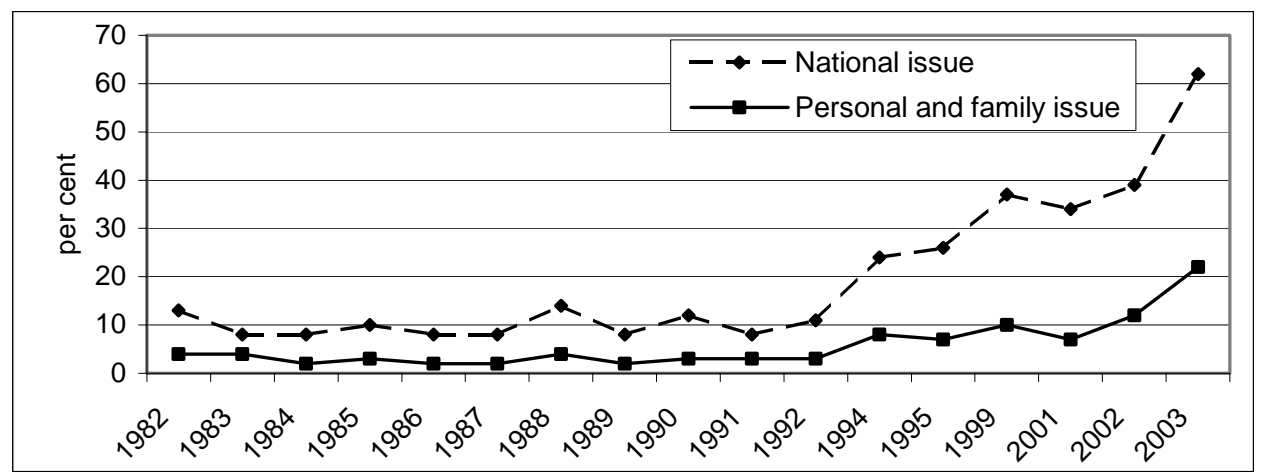

Question 1: Thinking about Australia as a whole. In your opinion, what are the three most important things the federal government should be doing something about?

Question 2: What could the federal government do that would be of most benefit to you and your family?

Source: Morgan Poll.

Because people know which services they want tax money spent on, they do not give unqualified support for more spending. In the 2003 ASSA a question that asked about spending on 'services like health and education' received a lower response than questions asking about either of those two services individually 
(68.2 per cent for health, 63.5 per cent for education). Only 57 per cent of the sample, however, replied affirmatively to both specific questions indicating that some people with limited pro-tax and spend views were presumably deterred by mention of a service that they did not want money spent on, and shifted their preference to 'depends', an option nominated by 21 per cent of respondents.

Vague questions, like those asked in the surveys that make up Figure 1, are likely to reduce pro-spending opinion. Questions which do not specify that the money is going to services that the respondents want, or raise the possibility that it might be spent on things that they do not want - 'services like [but not only] health and education'(emphasis added) - receive more negative answers than tightly-worded questions focusing attention on services respondents do want.

\section{The psychology of the surplus}

Most Budgets in the Howard-Costello era delivered surpluses, collecting more in tax and other government revenue than they spent. This reversed the budgetary pattern of the preceding 25 to 30 years. Since the mid-1970s, in most years governments spent more than they collected, and filled the gap with borrowing. The issue here is whether this fiscal turnaround changes the way people think about taxing and spending issues. Is spending more attractive if it does not require any new taxes, tax rates, or tax brackets? Are voters more likely to reject a tax cut paid out of the surplus than to accept a tax increase from an in-balance budget?

In strict personal financial terms, a surplus should not make a difference. A forgone $\$ 20$ a week tax cut out of a surplus has the same effect on personal finances as a $\$ 20$ tax increase from a balanced budget - the taxpayer is $\$ 20$ a week worse off. However, psychologically the two are not necessarily the same, and rejecting a tax cut is more likely than accepting a tax increase. This is because the taxes that finance surpluses are already factored into taxpayers' financial calculations. Rejecting a tax cut will not interfere with otherwise anticipated spending by a taxpayer. A tax increase, by contrast, would reduce forecast spending capacity. It hurts less to lose something you did not expect to have than to lose something you did expect to have.

The psychology of the surplus helps explain differences between the 2003 ASSA and the May 2003 ACNielsen poll. The 2003 ASSA omitted mention of a budget surplus and, as noted, 57 per cent of its respondents replied affirmatively to paying more tax for both health and education. The May 2003 ACNielsen poll, by contrast, found that 77 per cent of voters preferred the $\$ 2.4$ billion allocated to tax cuts to go to health and education (Stirton, 2003). That is 20 percentage points more support than for the same spending options when funded from increased personal tax, consistent with spending being less painful when it comes out of the surplus, even when accompanied by a lost tax cut.

Similarly, support for spending was above 57 per cent in other polls that referred to or assumed knowledge of the surplus. The January 2004 Newspoll, which specifically mentioned the surplus, came out 15 percentage points ahead of the 2003 ASSA for spending on a comparable combination of services, and 31 
percentage points higher if the money was to be split between spending and tax cuts. The May 2004 Taverner poll, also in the context of a Budget with a surplus but not directly reminding its respondents of it, found 65 per cent for more spending on services rather than the tax cuts, and 14 per cent for some of each. It had the lowest margin over the 2003 ASSA, eight percentage points, probably because it did not specify popular health and education spending.

\section{Framing losses}

The factored-in cost (from the taxpayers' point-of-view) of the surplus also changes how losses and gains are perceived. The psychological literature on loss aversion finds that, in normal circumstances, losses loom larger than gains (Kahneman, Knetsh and Thaler, 2000). To put it another way, most people are more upset about losing $\$ 100$ than they are happy about gaining $\$ 100$. When extra money is taken from voters in tax, it will be seen as a loss to the taxpayer. However, when the money is already held by the government (or will be held, given current tax rates and revenue projections) not spending the money on services becomes the 'loss' in people's minds, rather than paying tax. There are signs of this phenomenon in recent polls.

The May 2003 ACNielsen poll, taken after that year's Budget, is a possible example. It was well known that the tax cut was only $\$ 4$ a week for average earners. In this context, it was easy to see the lost health and education services as exceeding the small gain from lower income tax, so 77 per cent went for more health and education spending. Similarly, the January 2004 Newspoll's question framed the issue as tax cuts or services financed from a surplus. Because the surplus was the status quo, the negative of a potential loss of health and education services outweighed the positive of a tax cut.

For people who are net beneficiaries of the tax and social service system the 2004-05 Budget was easily framed as a 'loss'. They receive negligible or no benefit from a tax cut, and therefore lack a gain on the tax side of the tax and spend choice. A Newspoll published in The Australian after the May 2004 Budget shows how these people can be losers without losses. Though the Budget contained no spending cuts, 22 per cent of those polled proclaimed themselves to be 'worse off' as a result (Shanahan, 2004). Ignorance may explain some of these replies, but other voters possibly believed that with a large surplus they were entitled to a share of it, and failure to receive that share was a 'loss'.

A second question in the January 2004 Newspoll illustrates the effect of framing losses particularly well. As we have seen, only nine per cent of its respondents wanted the surplus spent all or mainly on tax cuts. But its next question asked whether the tax rate of 47 per cent on incomes over $\$ 62,500$ was too high. 50 per cent said it was, 34 per cent said it was about right, and just 8 per cent said it was too low. If the strict logic of answers to the first question were carried through a 50 per cent too high response would be unlikely, since without those high rates the projected surplus would not have been so large. Yet this 
second question was phrased to emphasise losses for taxpayers. The way the two questions were asked generated intuitive but inconsistent answers.

Another example of how framing the issue to emphasise the cost to taxpayers produces anti-tax results comes from an ACNielsen/CIS poll in August 2003. This survey told respondents how much taxpayers on $\$ 30,000, \$ 60,000$ and $\$ 120,000$ paid in tax, and asked whether this sum was too high, too low, or fair and reasonable. Put in these terms, the constituency for lower tax changes, from 9-20 per cent in the three questions premised on the surplus, to 41-46 per cent, depending on the income group (Saunders, 2004:9). Taxes mentioned in isolation are seen as losses to taxpayers. Just 1-9 per cent, again depending on the income group, thought that the tax paid was 'too low', well below the 27 per cent wanting more taxing and spending in all five areas suggested in the ASSA being conducted at the same time. The difference was that ACNielsen poll talked only about tax, focusing attention on tax losses, while the 2003 ASSA talked about taxes and services.

Such are the contradictory impulses about gains and losses prompted by different questions that when offered the status quo more respondents choose it above either lower tax or more spending alternatives. The status quo was also the most popular option when Figure 1 showed 'less tax' to be in the majority when answers were restricted to two alternatives. A 1979 Age Poll found that 61 per cent of respondents wanted the budgetary status quo, while 20 per cent wanted less tax. This contrasts with 59 per cent for reduced taxes when the choice was between less tax and more spending. Another Age Poll in 1985, just prior to the anti-tax peak in Figure 1, found 22 per cent preferring less tax and 57 per cent supporting the status quo (Grant, 2001:237-38). In 2000, the International Social Science Survey found 42.6 per cent support for the status quo, 30 per cent support for more taxing and spending, and 24.7 per cent for less (Withers and Edwards, 2001:13). This approximately matches the more spending option in the 2001 $\mathrm{AES}$, but shows 20 percentage points lower support for less tax.

What results from the one-off surveys suggest is not ideology, but opinion that is acutely sensitive to context. Often, this context is nothing more than the question asked and which concerns it makes salient. The importance of question wording has always to be kept in mind when analysing these polls. Question wording cannot, however, explain the trends recorded in Figure 1, because the questions asked were similar (the main differences are the absence of 'it depends' or 'mildly' options prior to 1984). Broader social, economic or political circumstances must be driving changing responses to questions that are the same or very similar.

\section{Underlying Causes}

\section{The importance of health}

The polls discussed so far suggest that the main reason support for tax has gone up is that voters want more money spent on health and education. One possible 
reason for this preference is that they believe these services are getting worse. Table 1 shows that a majority of voters believe there has been a decline in the standard of health service and a plurality think that the standard of public education has declined. In their article analysing the 2003 ASSA, Shaun Wilson and Trevor Breusch (2004) find that, after controlling for other factors, those who believe that health and Medicare have declined in the last two years support more spending by half a point more on a five point scale, and those who think public education has declined move toward more spending by a third of a point. Those who think both have declined move by three-quarters of a point. Richard Grant's (2004:25) paper also takes the view that support for more spending 'probably reflects the need to redress the perceived decline in health service standards'.

\section{Table 1: Perceptions of Service Standards}

$\begin{aligned} & \text { Question: Standard of health services since the [1996/1998] federal election has... } \\
& \text { Question: Over the last two years [since 2001], do you think that the standard of health } \\
& \text { services, including Medicare, has... }\end{aligned}$
\begin{tabular}{l|ccc}
\multicolumn{4}{c}{} \\
\hline & 1996 to 1998 & 1998 to 2001 & 2001 to 2003 \\
\hline Increased & 12 & 13 & 15 \\
Stayed the same & 25 & 33 & 24 \\
Fallen & 63 & 54 & 59 \\
\hline
\end{tabular}

Question: Quality of education since the [1996/98] federal election has...

Question: Over the last two years [since 2001], do you think that the standard of public education has...

\begin{tabular}{l|ccc}
\hline & 1996 to $\mathbf{1 9 9 8}$ & $\mathbf{1 9 9 8}$ to 2001 & 2001 to 2003 \\
\hline Increased & 11 & 12 & 15 \\
Stayed the same & 39 & 41 & 35 \\
Fallen & 50 & 47 & 42 \\
\hline
\end{tabular}

Note: The increased and fallen responses have been aggregated, and all figures rounded.

Source: Australian Election Survey 1998, 2001; Australian Survey of Social Attitudes 2003.

This explanation of opinion trends assumes that what is new is declining service standards, or at least a perception of declining standards, which in turn prompts voters to the conclusion that government spending must rise, drawing on the surplus or new taxes. But what if this perception is not new? A constant cannot explain something that varies over time. Polling conducted over many years suggests that far from dissatisfaction with health and education services being something that developed suddenly between 1996 and 1998, it is a phenomenon that appears regularly in the polls.

Though earlier questions about health did not ask about trends, we can infer from their answers that health services were a major concern. Back in 1984, when 
the polls were strongly for less tax, the National Social Science Survey (NSSS) nevertheless found that 57 per cent of people believed that too little was spent on hospitals and medical care. The 1987-88 NSSS found 70 per cent wanted more spending on 'health, hospitals and medical care'. In the 1990 Australian Election Survey, 89 per cent classed health as an important issue, but 51 per cent disagreed with increasing tax to finance more health spending. It took the direct threat of more tax to push health down the list of priorities.

Other sources confirm health services were important before the strong protax and spend polls of the last two years. Right from the time Newspoll started measuring opinion on health and Medicare in July 1990 it has been an important issue, with a debut on 63 per cent. It was at 85 per cent in October 2003 when the 2003 ASSA was being conducted. It did not show as highly significant in the Morgan Poll until later because economic issues, especially unemployment, were seen as more critical when poll respondents were permitted only three 'most important' issues. As the economy subsided as a concern, underlying concerns about health services rose to the top of the public's agenda.

It is conceivable that dissatisfaction with the quality of health services is the dynamic influence on public preferences; that over the last few years we reached a tipping point that reversed opinion on taxing and spending. Perhaps the demographic and technological changes driving up health costs finally overwhelmed the system and the public's patience. But a more plausible interpretation might be that health services have been a major concern for a long time without any dramatic effects on opinion about government spending. From 1986 to 1996, support for more spending overall was below 20 per cent - a number that doesn't match with the concern shown in specific questions about health during this time. As late as 2001 less tax had a trending down, but still comfortable, 12 percentage-point lead over more spending. Voters undoubtedly want health services to improve, but this fact on its own does not fully explain the trends we see.

\section{The impact of prosperity}

An alternative theory of tax and spend trends is that what varies is not the desire for better health and education services — this is an underlying constant — but the capacity to pay for them. In other words, prosperous people want to buy additional health and education services, along with other new or improved goods and services, which they forgo when they feel less well-off. Richard Grant, Shaun Wilson and Trevor Breusch correctly identify negative perceptions about health and education services as a necessary condition for voters supporting more taxing and spending, but miss that these perceptions are not on their own a sufficient condition for opinion to change.

If we look back on the long-term history of opinion on taxing and spending, going back to the late 1960s (Figure 1), this theory fits more closely with the trends we see. The last time we saw strong pro-spending opinion was in two surveys conducted in 1967 and 1969. This was a period of strong real wage 
growth. If people judge their financial situation by comparing it with the past then at that time they should have felt prosperous. Contemporary opinion polls suggest that they did, as seen in Table 2. Two Morgan polls conducted in 1966 and 1967 found that hospitals and medical services topped the list of most important election issues, with education second, just as they have again since $2001 .^{1}$ In these circumstances, it is plausible that in the late 1960s Australians wanted to increase their overall consumption, and for services (like health and education) where government was the dominant financier, they accepted that the mechanism for doing so was more taxation.

\section{Table 2: Late 1960s Feelings of Prosperity}

Question: Are you and your family better off now than you were three or four years ago, are you worse off, or have you stayed about the same?

\begin{tabular}{l|ccc}
\hline Year & Better off & About the same & Worse off \\
\hline 1967 & 40 & 39 & 20 \\
1969 & 43 & 42 & 14 \\
\hline
\end{tabular}

Source: Australian National Political Attitudes Survey.

By the time Australians were next asked about their preferences for taxing and spending, in 1974, opinion had changed markedly, against spending and for less tax. What drove this shift? Perhaps the Whitlam government's spending increases satisfied some demand for more services. A consequence of increased spending was that the tax burden rose from 22.5 per cent of GDP in 1972 to 25.9 per cent of GDP in 1974 (OECD, 2003:73-74). Though real wages were still growing, by the mid-1970s, the marginal tax rate on average weekly earnings exceeded 40 per cent (Warren, 2004:108). Additional tax hit many families' finances, and consistent with what we would expect if household finances were the main variable, support for less tax greatly increased.

At the time of the mid-1980s anti-tax peak in opinion, as seen in Figure 1, households' overall financial situation was worse than in the 1970s. Wage increases were not keeping pace with the cost of goods and services. Average income tax rates trended up to a record peak in the late 1980s, and the marginal tax rate on average weekly earnings exceeded 40 per cent for several years from 1985 (Warren, 2004:108). In 1983, the McNair polling organisation asked 'during the last few years has your financial situation been getting better, getting worse, or has it stayed the same?' - a similar though not identical question to that asked in

1 Morgan Result supplied by Richard Grant. There had been a House of Representatives election in 1966 and a Senate election in 1967. The question format differs from the later Morgan Polls in Figure 2, as respondents were asked about what would affect their vote rather than which issues the federal government should be doing something about, and they were given a list of 11 issues to choose from, rather than being asked to nominate their own issues. 
the late 1960s. 48 per cent said worse off, 36 per cent said the same, and only 14 per cent thought that they were better off (McNair, Anderson 1983). In 1987, a twelve-month comparison in the Australian Election Survey found 43 per cent thought that they were worse off, 38 per cent said the same, and 19 per cent said they were better off. The public chose lower tax over more spending, needing financial relief more than additional services. Consistent with this, as can be seen in Figure 2, few people rated health as one of the top three issues the federal government should be doing something about.

The overall household financial situation in the later 1990s and early 2000s was quite different. Real wages grew strongly from the mid-1990s, easing financial pressure on households. After the Howard government's 2000 tax reforms the marginal tax rate on average weekly earnings was 30 per cent, less than it had been through most of the 1970s and 1980s. Consumer confidence surveys, such as those carried out by Roy Morgan Research since 1973, show that people did perceive their financial situation in the way the objective statistics suggest they might have. From 1984 to 1987, the period of the anti-tax peak in opinion, confidence declined significantly and, apart from one exception in 1988, did not exceed its baseline 100 index until 1993. Since 1994, the consumer confidence index has not dropped below 110, and has exceeded 120 since 2002 (Roy Morgan Research, April 2004).

\section{Figure 3: Consumer Confidence and Preference for Social Service Spending}

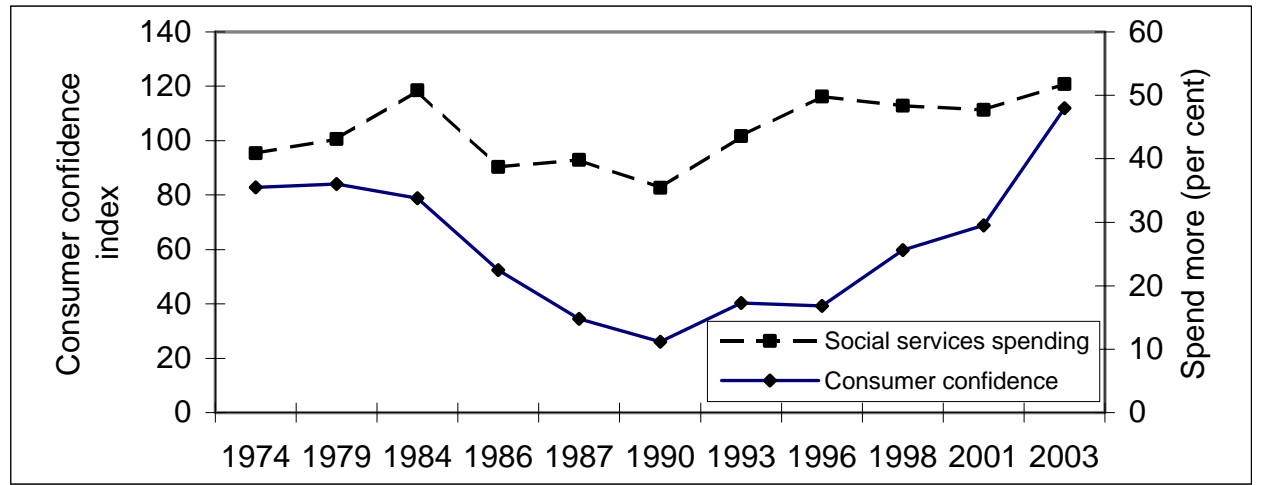

Source: Consumer confidence data is from 'Fall in April but Consumer Confidence Still High: Monthly Roy Morgan Consumer Confidence Figures - 1973 to present', Article No. 320, 16 April 2004.

Spending data: As for Figure 1.

We are back where we were in the late 1960s. Voters feel more prosperous than they did in the 1970s and 1980s, and want to buy more goods and services, including those services primarily financed through government. Figure 3 shows that for nearly a thirty-year period consumer confidence and support for spending 
on social services broadly track each other, as we would expect if financial circumstances are the key variable driving trends in tax and spend opinion.

\section{The View from Parliament House}

If tax cuts are less popular than at any time since the late 1960s, and extra spending, especially on health, has high support when paid for from increased tax and overwhelming support if financed from the surplus, why did the 2004-05 Budget not follow those preferences, and why did Labor also include tax cuts in its policy package?

\section{Tax cuts are short-term, but spending is long-term}

So far there is little evidence that voters' preferences are undergoing an enduring change. The force driving the polls is not ideology but prosperity. Without strong economic growth consumer confidence will drop and budget surpluses disappear. With the preconditions of pro-spending opinion gone, public preferences could quickly change. Since 1967 that has already occurred twice over five year periods, 1969 to 1974 and 1998 to 2003. If these poll results survive hard economic times then we can conclude that underlying opinion is different. Until then, the safer hypothesis is that recent survey results reveal a stage in a longerterm cycle, not a new resting point. Political leaders need to think of the longerterm consequences of anything they do now, and what options they will have if circumstances change.

Of the three options in the 2004-05 Budget - more spending, deficit reduction, tax cuts - more spending is the most politically difficult to adapt to a weaker economy. This is because while tax cuts and more spending can have the same effect on the current year's fiscal outcome, they have different longer term dynamics. Tax cuts mean that revenue is lower than it would otherwise have been, but cuts of the kind announced in the 2004-05 Budget do not disrupt the tax system's capacity to generate ever-increasing revenue from the same rates. This dynamic improves the Commonwealth's fiscal position. Spending increases, and especially those increases that create new entitlements also tend to grow, but these worsen the Commonwealth's fiscal position.

The progressive tax system can increase revenue even in a stagnant economy. With inflation, workers are pushed into higher tax brackets without any politically difficult tax increases. In a growing economy, real income increases push more workers into higher tax brackets, while tax rates stay the same. Due to these factors the proportion of taxpayers in low tax brackets - paying a top tax rate of 30 per cent or less - decreases each year by 1.5 to two percentage points, all without the government doing anything (Warren, 2004:110). Despite the tax cuts, the 2004 Commonwealth Budget predicts real tax revenue growth of 2.7 per cent in 2004-05 and 2.3 per cent in 2005-06. Only serious recessions, such as those in the early 1980s and early 1990s, reduce tax revenues in real terms. 
The expenditure side of the Budget lacks the tax system's self-correcting (from the Commonwealth's view) mechanisms. To the contrary, it has selfexpanding systems, causing spending to rise continually. Demographic change means that some areas of Commonwealth spending, such as old age pensions, cannot easily be controlled. Without controversial policy changes, the relatively easy qualifying terms for single parent and disability support benefits are likely to generate further growth in welfare dependency.

For politicians trying to manage economic and electoral cycles, moderate tax cuts are the safer option, causing fewer long-term fiscal problems.

\section{Private truths, public lies}

Voters tell pollsters that they favour more tax for more services, but how strongly do they hold this opinion? For some voters, their answers may reflect not deep beliefs, but what they think other people believe. They are bandwagon responses. With several well-publicised polls over 2003 and 2004 showing popular support for more spending, we have the basic precondition of a bandwagon effect. Bandwagon answers are not lies, but they are so superficial that a change in realworld events (such as taxes going up) could see these respondents switch sides very easily.

Other respondents may have firm preferences that they conceal for reasons of social acceptability. This is the 'private truths, public lies' phenomenon described by Timur Kuran in his book of that name (Kuran, 1995). With a national consensus that public services should be a top priority, nominating something else, especially something self-enriching like tax cuts, looks selfish. In these circumstances, some people give the answer they feel they should give, the socially or politically safe response, not what they genuinely believe.

The Morgan Poll 'most important issues' surveys give us some insight into differences between public and private opinion on political issues. By inquiring about what would benefit the respondent and his or her family, as well as what should be done for Australia, there is a question that minimises pressure to give the socially acceptable response - especially as the personal question is asked second, after good citizen bona fides are established. As Figure 4 indicates, tax is always more often nominated as something that the federal government could do for respondents and their families than it is nominated as a national issue.

The last two years are particularly interesting. While all other polling data suggests that tax levels are less of an issue than in the past, tax has increased significantly as a personal and family issue. This is consistent with, but not proof of, some voters telling 'public lies' that conceal their true policy preference. It could be that the minority who want tax cuts rank that issue above all others. Whatever the correct interpretation, Figure 4 warns politicians of a constituency still very concerned about how much tax they are paying, despite the pro-tax impression given by other polls. 
Figure 4: Tax as a National and Personal/Family Issue

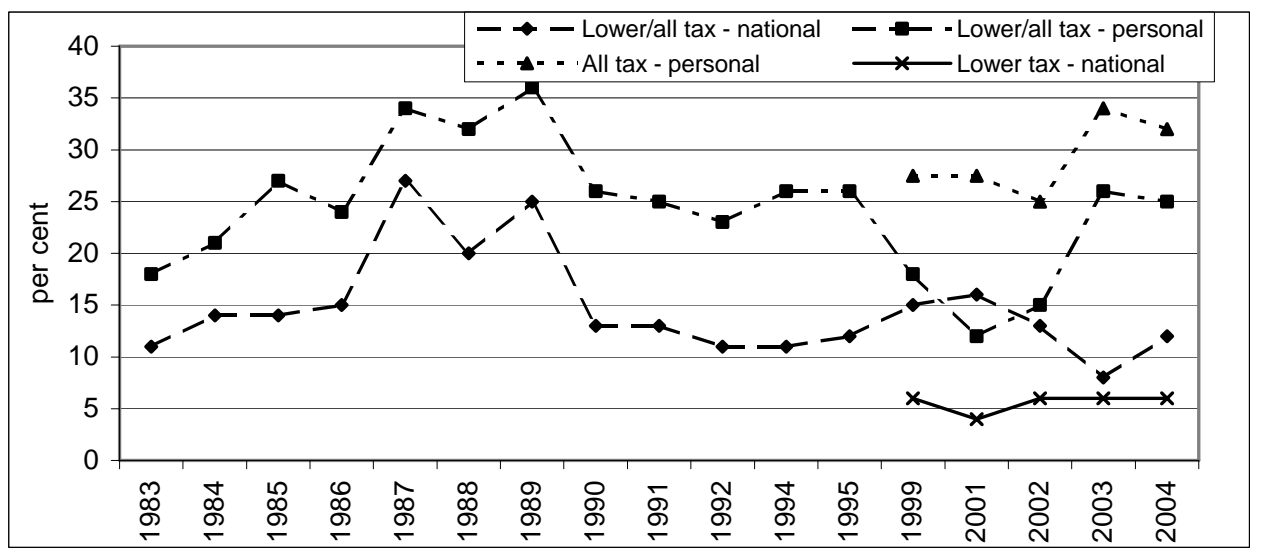

Question 1: Thinking about Australia as a whole. In your opinion, what are the three most important things the federal government should be doing something about?

Question 2: What could the federal government do that would be of most benefit to you and your family?

Note: Until 1999, all tax responses were classified by Morgan as 'lower tax'. After that, 'no GST', 'tax reform' and 'other taxation issues' were added. This creates difficulties in drawing trend lines. In that period 'lower tax' as a personal issue drops significantly, but taxation issues more broadly are stable. Pre-1999 some complaints about the tax system were probably coded as complaints about tax levels, though prior to the GST it is unlikely that this was a major factor. At least some of 'no GST' could probably be re-classified as a complaint about tax levels. The particular point of interest here, results from 2003 on, is unaffected by these changes.

Source: Morgan Poll.

What, me?

It is easy to say sincerely that other people should pay more tax. This is one reason why retirees, who have largely ended their taxpaying years, are much more in favour of spending than workers (Wilson and Breusch, 2004:111). But in addition to those who will never suffer the financial consequences of their preference, some people who support higher tax may do so because they believe that they will not pay, or will not pay much. However, many people erroneously believe that they are not in the top group of relatively high income-earners who pay most of Australia's income tax. Research by the Social Policy Research Centre at the University of New South Wales shows that many affluent Australians significantly underestimate their position in the nation's income distribution. When asked which income decile they were in, only two per cent of those in the top 20 per cent of earners located themselves correctly (Saunders, 2002:204-05). These people may change their preference after the first Budget that increases taxes. 
Others volunteering the 'wealthy' to pay more tax may not realise that, due to high marginal tax rates on modest incomes, they will end up paying more themselves in the near future. Neil Warren (2004:111) estimated, using the tax scales applying before the 2004-05 Budget, that as early as 2005 the average worker will move into the 42 per cent marginal tax rate (though of course their average tax rate will be much lower, because most of their income will taxed at 30 per cent or less). Average workers paying marginal tax rates above 40 per cent were a feature of strong opposition to more tax in the 1970s and 1980s, and there are signs that marginal tax rates are still an issue, such as the January 2004 Newspoll which found 50 per cent thought that 47 per cent tax above $\$ 62,500$ a year was too high. The Howard government's tax cuts delayed expanding the base of taxpayers paying high marginal tax rates.

Another difficulty is that as voluntary taxation creates free-riders, tax cannot be targeted on those willing to pay. Even for relatively popular spending priorities like health and education, we still see between one-quarter and one-third of voters in the 2003 ASSA saying that they are not willing to pay any more tax. In their analysis of that survey, Wilson and Breusch (2004:108-09) note that those without any political party identification are more in favour of tax cuts than other voters. These are also the people whose votes are most likely to swing in an election campaign, and the subject of political attention disproportionate to their numbers.

\section{Conclusion}

Like other recent analyses of public opinion trends, the preceding analysis finds that there has been a real shift in public opinion toward more spending on health and education and against lower taxes. That six pollsters asking a range of differently worded questions received similar answers gives us confidence that the trends identified in Figure 1 are real, and not the result of an idiosyncrasy of any particular survey. It is more difficult to be confident about the scale of this shift, because results are highly sensitive to context. This, however, does not show incoherence in opinion; rather it shows that the precise nature of the trade-off between the two alternatives matters, as we would expect from a rational voter.

The paper agrees with the other main papers - Grant (2004) and Wilson and Breusch (2004) - that the perceived quality of health and education services is a major factor. ${ }^{2}$ However, this is seen as a constant factor in voters' calculations, rather than the variable driving opinion change. Instead, economic prosperity is seen to have given voters the capacity to satisfy their preference for better health and education services. This has significant consequences for the interpretation of

\footnotetext{
2 A referee inquired about the influence of socio-economic and other characteristics on attitudes. Wilson and Breusch (2004) show that these vary in largely predictable ways, according to ideology and financial interest. However, they do not argue that overall trends are driven by sub-groups either changing their views dramatically or their share of the overall population. Opinion is moving more quickly than social change and by more than any one sub-group could trigger, so it is agreed that we need to look elsewhere for explanation.
} 
the political implications of this opinion shift. It does not seem likely that support for more spending will survive an economic downturn - economic rather than ideological change is most important. It follows that politicians need to be wary of making commitments that they cannot easily take back if opinion changes, or if opinion turns out to be insincere, or if voters wrongly assume that someone else will pay. At least for the meantime, opinion has changed, but these are polls politicians should not rush to act upon.

\section{References}

So as not to clutter the text with referenced, I have not individually noted precise locations of data from the Australian National Political Attitudes Survey, the National Social Science Survey, the Australian Election Survey, or the Australian Survey of Social Attitudes. These are all available from the Australian Social Science Data Archive at the Australian National University, http://assda.anu.edu.au/, along with full bibliographic details and information about sample sizes. Newspoll's results can be found at http://www.newspoll.com.au. More recent Roy Morgan polls can be found at http://www.roymorgan.com.au.

Australian Council of Trade Unions (2003), 'Government Services and Tax Resolution', ACTU Congress.

Gibson, R. (2004), 'Online Poll Report for Sunday 19 September 2004', unpublished paper, data summary available at: http://www.anuinnovation.com.au/pages/19_SEPT.pdf.

Grant, R. (2001), 'Parties, Press and Polls: Institutional Influences on Public Attitudes to Social Security and Health Policy in Australia, 1945-99’, unpublished thesis, Australian National University.

Grant, R. (2004), 'Less Tax or More Social Spending? Twenty Years of Opinion Polling', Research Paper No. 13, Parliamentary Library, Canberra, http://www.aph.gov.au/library/pubs/RP/2003-04/04rp13.pdf

Hudson, P. (2004), 'Poll Shock for PM as Budget Misfires', The Sunday Age, 16 May.

Kahneman, D., J. Knetsch and R. Thaler (2000), 'Anomalies: The Endowment Effect, Loss Aversion, and Status Quo Bias’, pp. 159-170 in D. Kahneman and A. Tversky (eds), Choices, Values and Frames, Cambridge University Press, New York.

Kuran, T. (1995), Private Truths, Public Lies: The Social Consequences of Preference Falsification, Harvard University Press, Cambridge, Mass.

Latham, M. (2004), 'Reply to Budget', delivered 13 May, available at: http://www.alp.org.au/media/0504/20007469.html

McNair Anderson (1983), The Changing Australian, Sentry Holdings/McNair Anderson, Sydney.

OECD (2003), Revenue Statistics 1965-2002, OECD, Paris. 
Quiggin, J. (2004), 'The Social Desirability of Social Democracy', http://www.johnquiggin.com/archives/001682.html, posted 8 May.

Roy Morgan Research (2004), 'Fall In April But Consumer Confidence Still High: Monthly Roy Morgan Consumer Confidence Figures - 1973 to present', Article No. 320, 16 April.

Saulwick, I. and D. Muller (2004), 'What the Pollsters Say’, The Age, 20 September.

Saunders, P. (2002), The Ends and Means of Welfare: Coping with Economic and Social Change in Australia, Cambridge University Press, Melbourne.

Saunders, P. (2004), 'What is Fair?’, Policy 20(1):3-10

Shanahan, D. (2004), 'Latham Steals Budget Bounce’, The Australian, 18 May.

Stirton, J. (2003), 'Voters Prefer Services to Tax Cuts', ACNielsen Issues Report, 19 May 2003. The poll was first reported in The Sydney Morning Herald, 20 May 2003.

Warren, N. (2004), Tax Facts, Fiction and Reform, Australian Tax Research Foundation, Sydney.

Wilson, S. (2004) 'The Voters Are Getting Restless, and Government Policy is Yet to Soothe Them', The Sydney Morning Herald, 3 May.

Wilson S. and T. Breusch, (2004), 'After the Tax Revolt: Why Medicare Matters More to Middle Australia than Lower Taxes’, Australian Journal of Social Issues 39(2):99-116.

Withers, G. and L. Edwards (2001), 'The Budget, the Election and the Voter', Australian Social Monitor 4(1): 9-14.

My work on this subject owes much to discussions with Richard Grant, his PhD thesis, and his archive of opinion polls. Christian Gillitzer, Peter Saunders and two anonymous referees offered useful suggestions for improvement. The usual disclaimers apply. A longer version of this paper is available at www.cis.org.au. 